\title{
Chapter 4 \\ Economics of Convention and its \\ Perspective on Knowledge and Institutions
}

\author{
Rainer Diaz-Bone
}

Knowledge and institutions can be conceptually related in different ways, and different institutional approaches offer different perspectives on this relation. This chapter draws attention to the French pragmatist institutionalism of the so-called economics of convention. I present the core concepts and methodological position of this approach and explore its perspective on knowledge, conventions, and institutions. Thereby, the economic institutionalism of transaction-cost economics (Ronald Coase and Oliver Williamson) has been influential in the field of economics, and Williamson's (1985) theory in particular has been important for the economics of convention as a counterpart.

Considering the relation between institutions and knowledge from the standpoint of acting and coordinating actors, one may question the idea of institutions as external constraints on action and coordination. One may also challenge the idea of pregiven meanings that institutions have for actors as it is thought in Williamson's (1985) transaction-cost approach and the economic institutionalism of North (1990). For economics of convention, the situational handling and meaning of institutions for coordinating actors is regarded as incomplete. This view points to the competence of actors to tap into deeper culturally established knowledge frames-called conventions - to interpret and deal with institutions in pragmatic situations. This position is the pragmatic process of "transferring" the institution into the process of action and coordination. It can be referred to as an internal conception of action and coordination.

The approach of economics of convention has been developed since the early 1980s in Paris. Although referring to economics, it is both general socioeconomic and sociological in character (Batifoulier, Bessis, Ghirardello, de Larquier, \& Rémillon, 2016; Boltanski \& Chiapello, 1999/2005; Boltanski \& Thévenot,

\footnotetext{
R. Diaz-Bone $(\triangle)$

Department of Sociology, University of Lucerne, Lucerne, Switzerland

e-mail: rainer.diazbone@unilu.ch
} 
1991/2006; Diaz-Bone, 2018; Favereau \& Lazega, 2002; Knoll, 2015; Orléan, 2014; Storper \& Salais, 1997).

Economics of convention is not a paradigm. It started as a scientific movement of French scholars working on a constellation of related problems and topics. From the outset, it has been transdisciplinary. This chapter begins by introducing the core theoretical concepts of the economics of convention, focusing on quality conventions as a key concept (first section) and emphasizing some of the approach's special features (second section). I then turn to the perspective that the economics of convention takes on institutions and knowledge (third section) and delineate the consequences of readjusting the notions of institution and knowledge (fourth and fifth sections). Economics of convention has generated many studies on regional economies, including Storper and Salais's Worlds of Production (1997), which compared logics of economic coordination in different regions. This model and some newer developments, such as the concept of global value chains, are then related to regional economic coordination (the sixth section). Because the economics of convention has proven capable of coping with global economic coordination as well, attention thereafter turns to development of the concept of global value chains to perform this task (seventh section). The chapter concludes with a summary of the main arguments and principles relevant for reflection on knowledge and institutions.

\section{Theoretical Architecture of Economics of Convention and its Core Concepts}

The best way to approach the economics of convention is to regard it as a scientific movement embedded in both French structuralism and sociological pragmatism (Diaz-Bone, 2018; Dosse, 1995/1999), the two megaparadigms of the social sciences. ${ }^{1}$ The analytical focus of economics of convention is on actors coordinating in situations where they have to achieve a common good, have a common goal, and need to resolve uncertainty about involved qualities and meanings.

Coordination is centered on the problem of manufacturing products, providing services, or generating other kinds of outcomes that can be valued and evaluated. Actors have to agree on the criteria and principles governing this valuation and evaluation and the qualities that characterize outcomes of their coordination. One core concept in this regard is the notion of convention. Conventions are not simply traditions, customs, or standards - as in Max Weber's sociology, for example (Weber, 1922/1978). The notion of convention in the economics of convention is complex, and it excludes most of the meanings the word has in other social theory. Conventions are not merely external constraints on or given facts for individual decision-making. As Storper (1997) observed:

${ }^{1}$ On structuralism see Dosse (1991/1998a, 1992/1998b, 1995/1999); on pragmatism, Kuklick (2001). 
[T]he social science of conventions rejects the distinction, common to modern economics, between decision-making rationality - as the ways in which individuals react to information-and action rooted in the pragmatic and cognitive acts of comprehension, understanding, or interpretation. It is not simply that different versions of comprehension, understanding or interpretation generate different "parameters" for decision-making in the form of different preference schedules or different things to be maximized, but that action leading to coordination is often necessarily a process of mutual comprehension, understanding, and commonality of interpretation between actors under conditions of uncertainty. . . Conventions are much more than mere cognitive, cultural, or psychological skills that permit actors to survive in markets. When actors undertake an activity, they do so with the expectation that they have a framework of action in common with other actors engaged in that activity. (p. 45)

Conventions can be defined as culturally established frames for the interpretation and evaluation of "what is going on" in situations. They are part of the implicit collective knowledge present in situations, and the skills of how to apply them are part of the competencies that actors have. Actors can thus draw on conventions as ways to engage and coordinate in situations to achieve a common goal. These goals can be conceived of as the collective production of qualities (e.g., goods and processes) and the realization of common goods. It is important to complete this definition by adding four aspects. The first is the view, as taken in economics of convention, that there is a plurality of existing conventions. The second is the approach's view of situations equipped with objects (e.g., instruments, machines, media) and "cognitive forms" for information on which actors rely for their action and coordination. The third important complementary aspect is that actors are regarded as being competent to mobilize conventions in situations and to evaluate conventions critically as appropriate or inappropriate (Storper \& Salais, 1997). The fourth is the emphasis that conventions are practical normative orders of worth that function as deeper logics for interpretation and evaluation but also for critique and justification of qualities and, hence, as logics of coordination intended to achieve a common good (Boltanski \& Thévenot, 1991/2006).

From the standpoint of economics of convention, conventions are necessary because the meaning of and interpretive approach to the relevance, working, legitimacy, adequacy, and, ultimately, use of institutions is not determined. This meaning of institutions is situationally incomplete. Institutions such as rules, contracts, laws, money, and language are regarded as incomplete because they (and their uses) are pragmatically embedded in situations in which the meaning of the institution for the precise application in a given setting cannot be specified ex ante. Actors must therefore decide on the adequacy of rules, contracts, laws, formal structures, or formal procedures-completing the situational meaning. To be clear, the notion of institution in the economics of convention is rather restricted to a formal and denotated (i.e., written down and formally representable) concept of institution. One may speak of a constrained concept. Institutions are thought of as the manifest dispositives for coordination. In this sense economics of convention shares a somewhat narrow conception of institution with economic institutionalisms, such as Williamson's (1985). However, in many other institutionalist approaches (which are represented in several of the contributions to this book), the concept of institution is 
understood more broadly to include informal structures as well, or what is called convention in economics of convention. Both approaches to defining institutions have their advantages and disadvantages. I show later in this chapter that both the narrower definition of institution in economics of convention and that definition's relation to the concept of convention bring in methodological strategies.

Researchers in the tradition of economics of convention try to adopt the standpoint of actors in situations of coordination in order to reconstruct actors' interpretations and the constellation of conventions that actors rely on when coordinating. Their notion of institution therefore cannot be regarded as a meso- or macroinstitutionalism, such as the notion of sociological neoinstitutionalism (see Meyer \& Rowan, 1977, and the contributions in Powell \& DiMaggio, 1991).

In economics of convention, it is important to see situations as equipped with objects and collective cognitive forms. Examples of these cognitive dispositives are numerical displays in factories or stories in small family enterprises. The numerical form is characteristic for the industrial world; the narrative form, for the domestic. As Eymard-Duvernay and Thévenot (1983) have demonstrated, collectivities, organizations, and enterprises need to invest not only in tools, machines, and other forms of material equipment but also in cognitive forms so that collectivities can recognize relevant information. In addition, the scope of coordination in time and space is extended by forms. This kind of investment is called form investment, or investment in forms.

Coordination in real situations is structured by a plurality of conventions (Boltanski \& Thévenot, 1991/2006; Diaz-Bone, 2018). The economics of convention is thus really a pragmatist approach, for pragmatism claimed for the recognition of ontological and political pluralism early on (James, 1909). The economics of convention rejects the idea that there is one best way to coordinate in situations of economic production, distribution, and consumption. Actors are considered competent to judge the appropriateness of conventions, to switch conventions, and to forge stable compromises out of different conventions or to criticize other actors grounding their critique on different conventions. Table 4.1 presents a set of eight important quality conventions as orders of worth and as logics of interpretation, evaluation, and coordination. The set is not arbitrary; these quality conventions are an established part of the sociocultural knowledge in western societies. Boltanski and Thévenot (1991/2006) presented a list of criteria ("axioms") to decide which "logic" may be regarded as a quality convention (p. 74). ${ }^{2}$

\footnotetext{
${ }^{2}$ There are six axioms that specify a logic of coordination as a convention that can be mobilized or enacted by a community (see Boltanski \& Thévenot, 1991/2006, pp. 74-78). The first axiom ("the principle of common humanity") holds that it is possible to identify members of the community who can apply the convention to establish equivalencies (not to be confused with equality) between these members. The second axiom ("the principle of differentiation") postulates that the different states (of value or worth) are possible for the members, based on the convention. The third axiom ("common dignity") states that all members of the community have the same power to access the different states in it. The fourth axiom ("the order of worth") claims that the different possible states are ordered (in terms of value or worth). The fifth axiom ("the investment formula") postu-
} 
Table 4.1 Eight conventions

\begin{tabular}{|c|c|c|c|c|c|}
\hline Convention & Worth/Quality & $\begin{array}{l}\text { Evaluation } \\
\text { criteria }\end{array}$ & $\begin{array}{l}\text { Information } \\
\text { format }\end{array}$ & $\begin{array}{l}\text { Persons' } \\
\text { qualification }\end{array}$ & $\begin{array}{l}\text { Interpersonal } \\
\text { relation }\end{array}$ \\
\hline Domestic & $\begin{array}{l}\text { Tradition, } \\
\text { handcraft }\end{array}$ & $\begin{array}{l}\text { Esteem, } \\
\text { reputation }\end{array}$ & $\begin{array}{l}\text { Oral, } \\
\text { exemplary }\end{array}$ & $\begin{array}{l}\text { Authority and } \\
\text { flexibility }\end{array}$ & Trust \\
\hline Market & $\begin{array}{l}\text { Demand } \\
\text { orientation, free } \\
\text { exchange }\end{array}$ & Price & Money units & $\begin{array}{l}\text { Desire, } \\
\text { purchasing } \\
\text { power }\end{array}$ & Exchange \\
\hline Industrial & $\begin{array}{l}\text { Planning and } \\
\text { standardization }\end{array}$ & $\begin{array}{l}\text { Efficiency, } \\
\text { productivity }\end{array}$ & $\begin{array}{l}\text { Measurable } \\
\text { criteria, } \\
\text { statistics }\end{array}$ & $\begin{array}{l}\text { Professional, } \\
\text { expertise }\end{array}$ & $\begin{array}{l}\text { Functional } \\
\text { link }\end{array}$ \\
\hline Inspired & $\begin{array}{l}\text { Grace, } \\
\text { nonconformity, } \\
\text { creativity }\end{array}$ & $\begin{array}{l}\text { Originality, } \\
\text { innovative } \\
\text { capacity }\end{array}$ & $\begin{array}{l}\text { Newness, } \\
\text { emotionality }\end{array}$ & $\begin{array}{l}\text { Creativity, } \\
\text { ingenuity }\end{array}$ & Passion \\
\hline Opinion & Renown & $\begin{array}{l}\text { Amount of } \\
\text { recognition }\end{array}$ & Semiotics & Celebrity & Recognition \\
\hline Civic & $\begin{array}{l}\text { Collective } \\
\text { interest }\end{array}$ & $\begin{array}{l}\text { Relevance for } \\
\text { collectivity }\end{array}$ & $\begin{array}{l}\text { Formal, } \\
\text { official }\end{array}$ & Equality & Solidarity \\
\hline Green & $\begin{array}{l}\text { Ecology (its } \\
\text { integrity) }\end{array}$ & $\begin{array}{l}\text { Environmental } \\
\text { compatibility }\end{array}$ & Narrative & $\begin{array}{l}\text { Ecological } \\
\text { knowledge }\end{array}$ & Responsibility \\
\hline Network & $\begin{array}{l}\text { Activity, } \\
\text { self- } \\
\text { management }\end{array}$ & $\begin{array}{l}\text { Successful } \\
\text { projects }\end{array}$ & Meetings & $\begin{array}{l}\text { Capacity for } \\
\text { teamwork }\end{array}$ & $\begin{array}{l}\text { Project } \\
\text { orientation }\end{array}$ \\
\hline
\end{tabular}

Source: Adapted from Diaz-Bone (2018, chap. 5). Copyright 2018 by author and Springer Fachmedien Wiesbaden

Critique for economics of convention is an everyday practice. Qualities are not only constructed and recognized but also questioned and tested. Critique thereby refers to quality conventions and objects. Critique and tests bring tensions into situations (Boltanski \& Thévenot, 1991/2006). Both also discover the empirical normativity of coordination. When it comes to pragmatism, normativity is not an issue left up to philosophers. Actors apply convention-based evaluations to persons, things, and actions, so these evaluations refer to the norms and values that conventions represent. Ordinary actors are thus competent in the business of everyday moralities. The daily quarrels and disputes about rights and wrongs center on questions of "appropriateness and justice" (justesse et justice) (Boltanski \& Thévenot, 1989). All in all, economics of convention has a clear antipositivistic claim: Norms and values are enacted and materialized in situations by the convention-based co-constructions of qualities, objects, and forms. Norms and values are empirical facts in situations; they are not metaphysical or philosophical "add-ons". Figure 4.1 presents the concepts of economics of convention and their relations to each other.

lates that the benefit of higher states are linked to costs and sacrifices, so self-centered pleasures have to be abandoned. According to the sixth axiom ("the common good"), higher states are related to a higher degree of happiness and goods and, hence, are closer to a common good. 


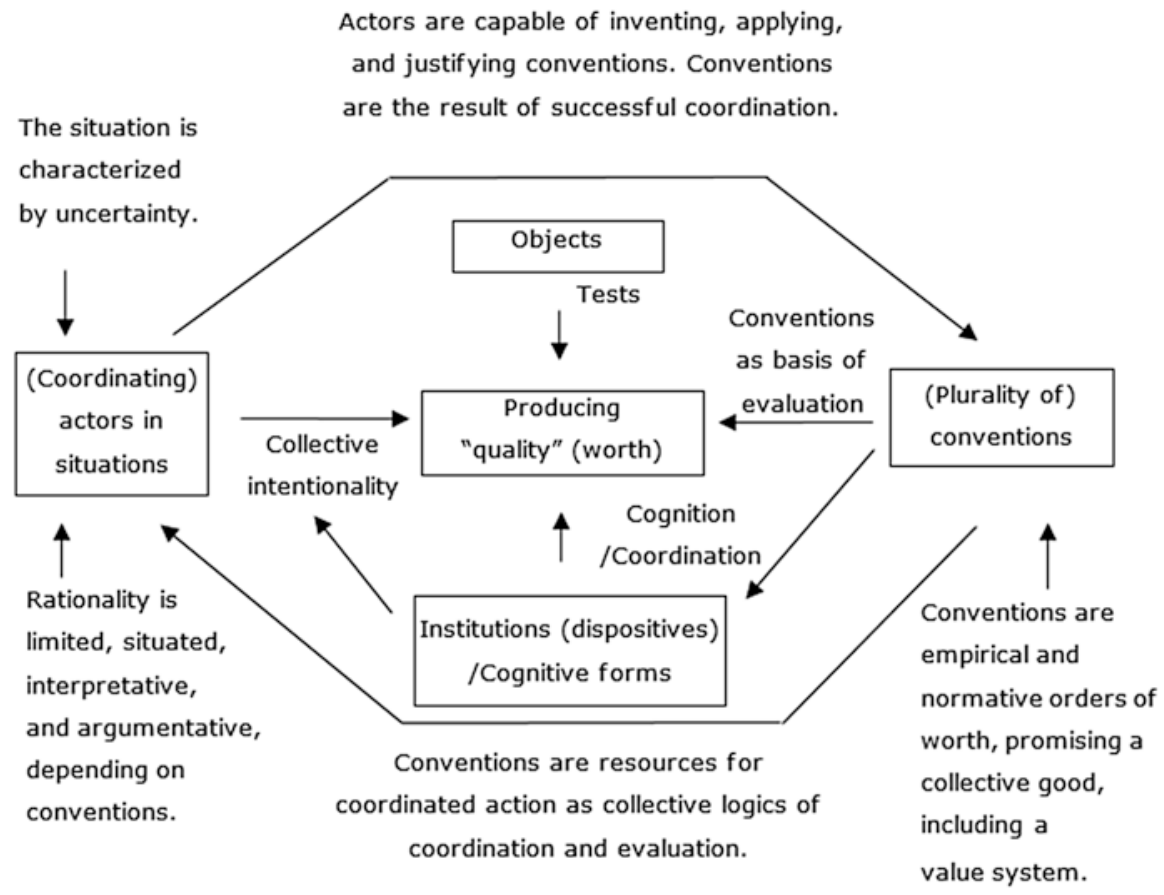

Fig. 4.1 Core concepts of economics of convention. Source: Design by author

\section{Why Convention Theory?}

Because economics of convention is influenced by structuralism and pragmatism, it is able to deal with theoretical aspects of action and practices as well as with aspects of cultural frames and institutions. It is not a single-issue approach. It cannot be reduced to the analysis of conventions alone (as shown in the previous section). To answer the question of why it has to offer innovative elements in the interdisciplinary field of institutionalism, consider the following four aspects.

\section{Reintegrating Empirical and Normative Analysis}

To understand the relevance of economics of convention, one has to recognize its interest: to grasp coordinating practices in situations wherein actors mobilize realities with qualities relying on normative orders. These qualities are closely linked to common goods and applied moralities. Economics of convention is therefore about social ontologies and social values-both are constructed and related to each other by competent actors in situations. The claim made by economics of convention visà-vis its counterpart, Williamson's (1985) economic institutionalism, is that 
economics of convention is an institutional approach, which reintegrates empirical and normative concepts in the analysis of the empirical coordination of actors who rely on everyday normativities for the purposes of production, distribution, and consumption. Its character is therefore general. It combines pragmatist and structuralist perspectives but also includes ordinary normativities as empirical realities (Boltanski \& Thévenot, 1991/2006; Storper \& Salais, 1997).

\section{Realizing a Transdisciplinary Practice in Institutional Analysis}

As mentioned in the introduction, the character of the economics of convention is transdisciplinarity. It integrates heterodox economics with pragmatic sociology, ${ }^{3}$ economic sociology, economic geography, and historical institutionalism without reducing the phenomena under study to only one principle. Today, many highly specialized and single-principle disciplines stand to lose their scientific objects of study. It is important to see that these specializations often coincide with the separation of methodological cultures, that is, the division of quantitative and qualitative methods. The economics of convention is different in these regards because it integrates the experience of many scientific fields and combines a full range of quantitative and qualitative methods that are divorced in other approaches (Diaz-Bone \& Salais, 2011, 2012). Moreover, it integrates the analysis of law into its institutionalism. It does not so through economic institutionalism and the law-and-economics approach (Posner, 2007), because in this approach, law is studied almost only as an external constraint on economic coordination. With economics of convention, by contrast, law is internal to action and coordination and must be enacted by convention-based processes of interpretation.

In most (national) sociologies, the subdisciplines of economic sociology, institutionalism, and sociology of law are separated by the way the discipline is organized and its research is published and taught. In that sense economics of convention is different because it combines the analysis of law, labor and economic institutions, economic valuation, quantification and classification, and economic coordination as related phenomena whose analysis has to include the transdisciplinary competence of social scientists (Bessy, 2012; Diaz-Bone, Didry, \& Salais, 2015; Diaz-Bone \& Salais, 2011).

\section{Using a Pragmatist and Structuralist Methodology}

Economics of convention was not developed from theoretical considerations only but rather in processes of empirical research in fields as industrial relations, markets, and a variety of economic sectors. The result is its open, theoretical character,

\footnotetext{
${ }^{3}$ On pragmatic sociology see Nachi (2006) and Corcuff (2011).
} 
which can be described as a network of concepts acknowledging a pluralism of conventions and competent actors in real and (with objects) equipped situations of coordination. Economics of convention also offers a corresponding methodological culture that brings in structuralist and pragmatist methodologies and combines them (Diaz-Bone, 2018). The special methodological view of economics of convention is its interpretation of emerging sociohistorical co-constructions of institutions, conventions, categories, practices, and problems (Salais, Baverez, \& Reynaud, 1999). ${ }^{4}$ Unlike transaction-cost economics and the law-and-economics approach, economics of convention rejects the idea that there is only one explanatory principle. The two former approaches apply an externalist methodology of explanation, explaining economic performance by the fit of institutional designs. For economics of convention, both the sociohistorical constellation and the agency that issues from it are a focus. They are related to actors' internal perspectives. The analyst adopts the standpoint of actors and studies the way actors interpret institutions and their meaning in situations of coordination (Diaz-Bone et al., 2015; Diaz-Bone \& Salais, 2011; Salais et al., 1999). The analysis of structures and actors' practices from an internal point of view enters through the proposal to integrate the methodologies of pragmatism and structuralism (Storper \& Salais, 1997).

\section{Addressing Contemporary Core Problems}

A fourth point calls attention to the contributions that the economics of convention makes to dealing with contemporary core problems of institutionalism, economic sociology, cultural sociology, and theory development. Key contemporary topics include the social construction of qualities or processes of valuation; the connection between norms, values, and practical action; the awareness of a plurality of institutional settings; and the inclusion of objects and cognition into sociological analysis. Economics of convention is one of the leading approaches in all these areas, and it continues to combine and develop pragmatism and structuralism.

\section{The Relation Between Knowledge and Institutions}

In economics of convention, not everything that exerts influence on human action is regarded as an institution (as in the Durkheimian tradition). Institutions are the tools (dispositives) of coordination, and actors marshal them to realize a common good. Economics of convention offers a special perspective on the relationship between institutions and knowledge. As mentioned in the second section, institutions are considered to be incomplete in terms of their meaning. This position has consequences.

\footnotetext{
${ }^{4}$ See also Latsis (2006), who analyzed the methodology of the economics of convention.
} 
1. Institutions are not regarded as external constraints but rather as dispositives that need to be embedded by competent actors in situational processes of shared interpretation, evaluation, and coordination. Institutions are enacted and therefore internal to actions.

2. Actors have to evaluate in situations the usefulness and adequacy of institutions as dispositives for the purpose of collective coordination. Institutions can be handled in different ways because they can be evaluated and their meaning can be completed through the use of different conventions.

3. Knowledge about conventions can be regarded as distributed and materialized in processes of coordination, which are stabilized by cognitive forms and conventionbased procedures for interpretation, evaluation, and coordination. Knowledge, therefore, is not located in individuals, media, or institutions as such but rather in structured processes that rely on actors' competencies, conventions, and dispositives. The model for this concept of distributed knowledge is the concept of distributed cognition developed by Hutchins (1995). He studied the navigation processes on a U.S. naval vessel and demonstrated the existence of calculative processes that were not restricted to individual human brains but distributed to positions, practices, objects, and actors all over the ship. No one person was able to perform the navigation, nor did any one person control or know all the necessary information about the navigation process on board. The economics of convention has adopted this perspective on cognition and transferred it to knowledge conceived of as a pragmatic reality residing in processes.

4. Learning and training for economics of convention are related primarily to processes and situations, not to individuals. To learn is to implement elements, which change these processes of interpretation, evaluation, and coordination. Training persons is related to trying to enhance environments and situations in which human beings are involved practically.

Favereau (1997) argued that organizational learning is possible just because the meaning of institutions is incomplete, as is the case with organizational rules. Learning articulates itself in the way organizational procedures handle and complement rules practically. Learning is possible by changing established rules and implementing new ones-which are likewise incomplete and need to be embedded in situational procedures of convention-based coordination.

\section{Institution: A Constrained Concept}

It should be clear by now that the notion of institution has less scope in the economics of convention than in other institutionalist approaches. In some varieties of institutionalism, the notion of institution denotes almost everything outside the human body, such as rules, organizations and technical infrastructures, culture and cultural patterns, language, law, and money. In the economics of convention, it is important to make a conceptual difference between what an institution is and what it is not. Otherwise, the nearly all-embracing notion of institution loses its analytical power. 
Table 4.2 Four perceived situations

\begin{tabular}{lll}
\hline Relation between an institution and & \multicolumn{2}{c}{ Functioning of an institution is judged as ... } \\
\cline { 2 - 3 } convention(s) is ... & \multicolumn{1}{c}{ "not critical" } & \multicolumn{1}{c}{ "critical" } \\
\hline coherent & (1) & blockage/hegemony \\
incoherent & normality/reliability & (4) \\
& $(3)$ & a crisis/a failure \\
\hline
\end{tabular}

Source: Design by author

Economics of convention thus enables one to use the difference between institutions (e.g., tools, or dispositives, of coordination) and conventions (as culturally established resources for evaluation and interpretation of how institutions should be run, brought to bear, and judged) to study four different situations illustrating possible ways to relate institutions and their embedding in convention-based interpretations, evaluations, and coordination. The situations can be differentiated as shown in Table 4.2.

The first situation can be characterized as an uncontested "normality." Institutions perform work (for the purposes actors pursue), and there is no reason to change them. The interrelation between convention(s) and institutions is perceived as mutually stabilizing. An example of this situation is the Parisian traffic system and traffic policy. The traffic system and the political (and contractual) control of the private enterprise RATP, which offers bus and subway stations not more than $400 \mathrm{~m}$ (a quarter of a mile) from almost any residence, with frequent connections for everybody at low cost, is perceived by the citizens (not as customers) as stable, reliable, and coherent with the civic and industrial conventions that actors use to interpret, handle, and evaluate the traffic system.

The first situation immediately changes into the second when actors judge the functioning of institutions to be critical. Criticism will mount because actors perceive the coherent relation of conventions and institutions as a problem. In this situation it is not easy to criticize institutions, for they are backed up by at least one convention and therefore experienced as blocked. An example is the control exercised over the French labor market (labor law and labor institutions), which is known to be highly regulated and protective of employees. It is coherent with the way French employees and labor law experts think about job security and actors' legal rights. The labor law is coherent with the related civic and industrial conventions. But many French employees experience this coherence as blockage because they are either not employed (unemployment in France has been high for decades) or have only temporary employment contracts. Employers are reluctant to engage employees on unlimited contracts because of the high amount of regulation and the major difficulties that dismissals entail. Many employees and employers alike are penalized by existing labor regulation and would prefer a more flexible and open labor regulation. The call to decrease the unemployment rate is prevalent in France, but no alternative regulation seems acceptable, so most employees, employers, unionists, politicians, and even many unemployed stick to the existing and coherent way of regulating the labor market. 
The third situation is different from the first and the second in that conventions and institutions are not coherently related. However, this situation can be the consequence of new strategies pursued by actors, changing conventions in relation to institutions so that new opportunities, outcomes, and values may be produced or may emerge. This situation will continue to cause change until it converges again with a more coherent one (see for example, Salais et al., 1999). An example is the rise of French industrialization in the Paris region in the early twentieth century (see, Didry, 2002). In keeping with market convention at that time, labor law did not allow collective labor contracts, for it was based on a liberal conception of contracts between individual (and noncollective) actors. But as industrial labor organization intensified, French law was perceived as no longer coherent with new conventions of labor coordination (the industrial and the civic convention). Judges (in law courts) gradually accepted new interpretations of existing labor law and even the deviation from existing law to reconcile it with the new need for collective contracts.

The fourth situation comes across as a problem, increasing the impact of the critique of institutional malfunctioning because of the incoherence between convention(s) and institutions. From the actors' point of view, institutions have failed; cognition turns into the recognition of a real institutional crisis (see Boltanski \& Thévenot, 1991/2006; Orléan, 2014, among others). For example, the 2017 presidential election in France made evident that the classical political elite, which for many decades had been divided into a left wing (socialist party) and a right wing (conservative party), would not be able to carry large parts of the electorate. The Gaullist voting system works well in a society with such a cleavage into two big political factions. In 2017 the new candidate, Manuel Macron, belonging to no traditional party, won the first round of the election with only $24 \%$ of the vote. No candidate from an established party managed to advance into the second round of the presidential election. In France the traditional socialist party and the conservative party are mired in a fundamental crisis - as is the electoral system itself. Current political movements (including Macron's en marche) are supplanting political parties. Many new candidates for political office at the local, cantonal, or departmental level no longer belong to a political party. The incoherence between existing political institutions and conventions is recognized and discussed as failure, but new forms of political mobilization and engagements are rising inexorably, heralding opportunity for political change.

In economics of convention, stability and dynamics are conceived of as stable or unstable constellations of conventions (and compromises between a plurality of them) and institutions. Socioeconomic dynamics, therefore, cannot be reduced to institutional change only, for institutions do not change themselves. In economics of convention, socioeconomic dynamic emerges from the relational processes and constellations between conventions, institutions, and coordinating actors in situations. Insisting on the difference between conventions and institutions protects economics of convention from reducing institutional analysis to the comparison between different institutional arrangements - as the transaction-cost approach does by incessantly comparing organizations and markets (Williamson, 1985). That approach thereby assumes that these institutional arrangements are opposed ideal 
types. Instead, Favereau (1989a, 1989b) has argued that markets are organized and that organizations cannot be reduced to systems of contracts. All quality conventions can be influential in markets as well as in organizations. Organizations and markets are not limited entities, and they cannot be defined in terms of simple categories. Both are embedded in overarching chains of situations, which are structured by conventions that actors apply as resources for wide-ranging coordination (Favereau, 2014).

\section{Knowledge: Conventions as Deeper Discursive Structures}

Although conventions can be regarded as logics of interpretation, evaluation, and coordination, they do not necessarily appear in the form of words and language. Many acts of interpretation, evaluation, and coordination are routine, and many of these processes do not need language use. Normally, conventions are used unconsciously, implicitly, and are not apparent as such. Boltanski and Thévenot (1983, 1991/2006) argued that actors are capable of bringing conventions to the surface when the quality of persons, actions, or objects is questioned. Actors then refer to conventions as practical metaphysics for the justification of qualities and worth, hence the reason why conventions can work as orders of justification. The economics of convention relates conventions to products as foundations for their quality. Exponents of the approach therefore speak of quality conventions.

The strategy of exploring quality conventions as foundations for quality arguments is to analyze discourses as knowledge structures that are internally organized by conventions understood as latent or deeper discursive patterns (Gomez \& Jones, 2000). ${ }^{5}$ Seen in this light, quality conventions are the discursive structures for economic institutions such as markets, for markets would collapse if there were uncertainty about product quality. In economics of convention, product quality is not an ontologically given property but rather a social construction based on quality conventions. An example is the quality of wine. One can study the German wine market by identifying the quality conventions that pattern the quality categories of wine produced in Germany.

Figure 4.2 sketches the wine market relating wine-quality conventions to organizational forms and resources (as different forms of capital) as a function of the market segment. Similar studies can explain that markets cannot be characterized by single and homogeneous product categories and product qualities (such as simple material properties). Evidently, market models like this one (based on convention theory) contradict the neoclassical conception of markets, which posits standardized and comparable product properties. For competent market participants this relational order of a plurality of quality conventions is the implicit knowledge of a market as an institution.

${ }^{5}$ For a similar interpretation of conventions as deeper structures, see Bessy and Chateauraynaud (2014). 


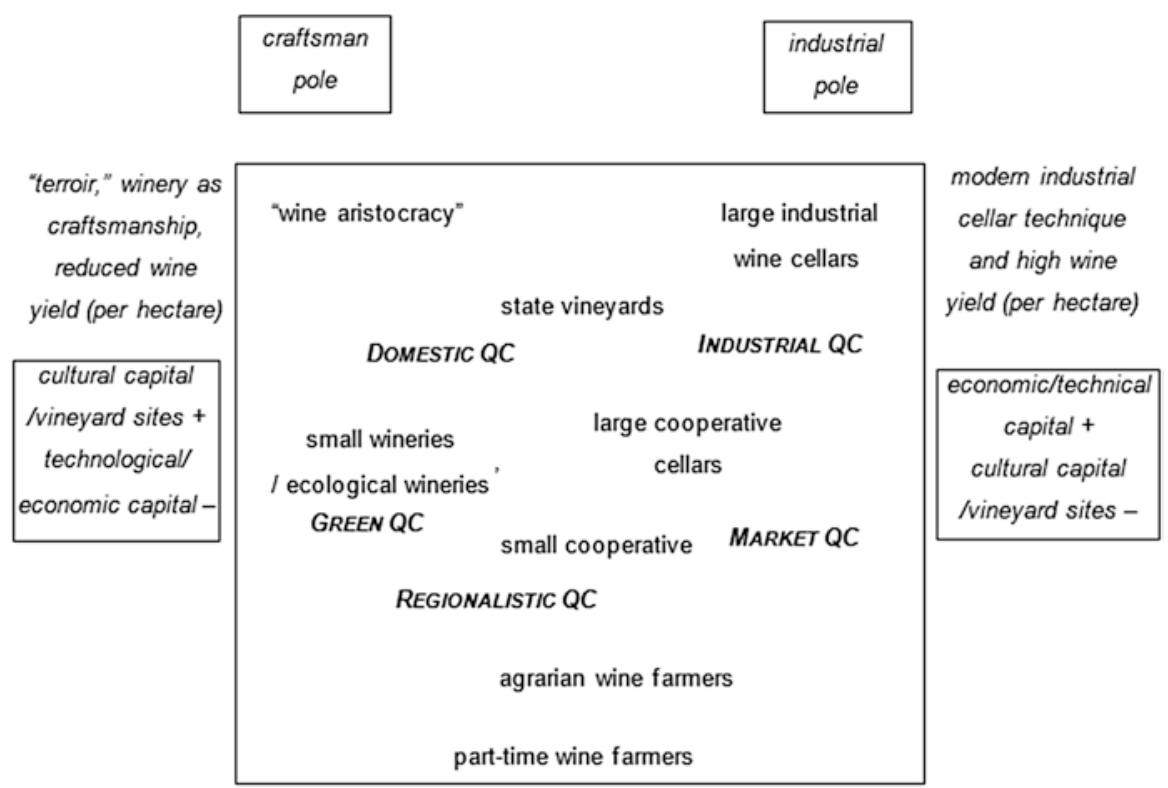

Fig. 4.2 Quality Conventions (QC) in the German wine market. Source: Diaz-Bone (2013, p. 53). Copyright by author

\section{Conventions and Regional Economies}

Economics of convention has opposed against two master narratives that are in fact linked to each other. The first one is the view of industrial mass production as the dominant way of organizing economic coordination and a way that would prevail over traditional forms of production such as craftsmanship. The second master narrative is the view of globalization as the second principle of how economic organization was distributed. Piore and Sabel (1984) criticized both views and identified regional economies that exhibited different forms of coordination as highly specialized small firms, which were embedded in regional and flexible networks. Instead of hiring unqualified workers, they engaged highly qualified craftsmen and technicians. They delivered specialized and high-quality products worldwide as well (not only to meet regional demand).

Salais and Storper (1997) elaborated a model-inspired by Piore and Sabel (1984) - presenting different logics of coordination, which they used in the comparative analysis of economic sectors located in regions where companies cooperated to manufacture products. Salais and Storper (1997) introduced the notion of "worlds of production" to describe these forms of regional cooperation. This concept of 
Table 4.3 Four Possible Worlds

\begin{tabular}{|c|c|c|}
\hline & $\begin{array}{l}\text { Specialized products } \\
\text { (economies of variety) }\end{array}$ & $\begin{array}{l}\text { Standardized products } \\
\text { (economies of scale) }\end{array}$ \\
\hline & The interpersonal world & The market world \\
\hline \multirow[t]{5}{*}{$\begin{array}{l}\text { Dedicated } \\
\text { products }\end{array}$} & Evaluation of quality: Price & $\begin{array}{l}\text { Evaluation of quality: Industrial } \\
\text { standards by demanders }\end{array}$ \\
\hline & $\begin{array}{l}\text { Forms of uncertainty: Personal qualities } \\
\text { of other producers and consumers }\end{array}$ & $\begin{array}{l}\text { Forms of uncertainty: Shifting prices } \\
\text { and quantities }\end{array}$ \\
\hline & $\begin{array}{l}\text { Response to uncertainty: Comprehension } \\
\text { among a community of persons }\end{array}$ & $\begin{array}{l}\text { Response to uncertainty: Immediate } \\
\text { availability }\end{array}$ \\
\hline & Basis of competition: Quality & $\begin{array}{l}\text { Basis of competition: Prices and } \\
\text { rapidity }\end{array}$ \\
\hline & The world of intellectual resources & The industrial world \\
\hline \multirow[t]{4}{*}{$\begin{array}{l}\text { Generic } \\
\text { products }\end{array}$} & Evaluation of quality: Scientific methods & $\begin{array}{l}\text { Evaluation of quality: General } \\
\text { industrial standards }\end{array}$ \\
\hline & $\begin{array}{l}\text { Forms of uncertainty: The path of } \\
\text { knowledge development }\end{array}$ & $\begin{array}{l}\text { Forms of uncertainty: Business cycle, } \\
\text { demand fluctuations }\end{array}$ \\
\hline & $\begin{array}{l}\text { Response to uncertainty: Confidence in } \\
\text { others }\end{array}$ & $\begin{array}{l}\text { Response to uncertainty: Short and } \\
\text { medium term forecast of events and } \\
\text { behavior }\end{array}$ \\
\hline & Basis of competition: Learning & Basis of competition: Price \\
\hline
\end{tabular}

Adopted from Storper \& Salais (1997, p. 33). Copyright 1997 by the President and Fellows of Harvard College. Reprinted with permission from the authors and the President and Fellows of Harvard College

worlds of production is as important as that of quality conventions. Both concepts share their character in the economics of convention as logics of coordination. And both are part of systems of such logics of coordination. Table 4.3 presents the four different forms of worlds of production. Their character as ideal types explains why Storper and Salais also speak of "possible worlds" of production (pp. 19, 26), relating them to two general polarities: "specialized versus standardized products" and "dedicated versus generic products" (p. 33). ${ }^{6}$

The model by Storper and Salais (1997) contradicts the master narrative of industrial mass production and globalization in two regards. First, Storper and Salais claim that there are many possible ways to produce, distribute, and consume products (and services). Second, they insist on the importance of the local and regional anchoring of coordination processes. The competencies and qualifications that are relevant ingredients for production are built up in situated and repeated processes, which require a regional center and identity. Moreover, they are related to economic coordination in other regions (and other sectors), so the regional and relational character of economic coordination has to be recognized (see, Bathelt \& Glückler, 2011; Storper, 1997).

\footnotetext{
${ }^{6}$ This categorization, or model of worlds of production, has its own grammar, just as the model of quality conventions has had its axioms.
} 
Economics of convention has focused on these regionally anchored processes of production. Processes of globalization and the unification of the European Union have strengthened regional identities, as indicated by the emergence of certifications and the establishment of labels such as the French AOC certificate (appellation d'origine contrôlée). From the perspective of economics of convention, labels and certification are necessary strategies and signals of form investment, which are dispositives for the ascription of qualities to products. The analysis of agrarian food production, therefore, has been an important application of economics of convention (see the contributions in Allaire \& Boyer, 1995; Nicolas \& Valceschini, 1995; Ponte, 2016; Sánchez-Hernández, Aparicio-Amador \& Alonso-Santos, 2010).

Economics of convention has an explicit link to the regional perspectivenamely, the methodology of situationalism, which consists of focusing on situations of coordination and adopting the actor's perspective (Storper \& Salais, 1997). Thévenot (2001) has argued for rejection of multilevel models and for their replacement by the notion of the scope of situational coordination: "[O]ur framework . . challenges the classical macro-micro distinction since judgements of worth are precisely ways of enlarging the scope of an evaluation from a local context and of crafting generalized statements" (p. 418).

Inspired by Storper (1997), one may consider introducing the regionalistic convention (Diaz-Bone, 2018). It would not be a convention established in a specific region but rather a specific way to coordinate and evaluate qualities of products. This capability would be valuable. Not only are products generated in a region (as almost every product is), their quality is attributed to it. As in the example of the German wine market (Figure 4.2), there are regional styles of production, regional taste cultures, regional traditions, and regional identities, all of which are perceived by coordination actors as being linked to the product. This regionalistic convention should be thought of as different from seemingly similar conventions, such as the domestic convention or the green convention, because it is not based on the principle of craftsmanship (as the domestic convention is) or ecological production (as the green convention is). By enlarging the scope of coordination, actors are able to extend collaboration from the local to the global level. The economics of convention questions the use of multilevel models, including micro-, macro-, and sometimes mesolevels of coordination, because those levels imply their own ontologies of entities residing at these levels. ${ }^{7}$ But to call this regional convention a convention, one must adopt the idea that these conventions have deeper grammars and criteria-a process still to be undertaken in economics of convention.

\footnotetext{
${ }^{7}$ And every multilevel model should be scrutinized for how it theorizes the ontologies related to the different levels and how it models the process that takes place between them.
} 


\section{Global Value Chains}

The global value-chain concept is an excellent example of how one can model wideranging global chains of coordination by adopting the theoretical perspective of economics of convention (Daviron \& Ponte, 2005; Ponte, 2016). ${ }^{8}$ This concept also aptly demonstrates how to model an institutionalist perspective (in this case, how to govern coordination across different stages of production) by focusing on the construction of quality. In a comparative study of coffee production and the social construction of quality, Daviron and Ponte (2005) surveyed the different stages in the production chain of coffee, studying how quality conventions were introduced and applied in different links of the chain. The same coffee beans figuring as raw material at the beginning of the global value chain can wind up as completely different coffee products at the end of the global value chain (as coffee blend) related to different quality perceptions. Daviron and Ponte (2005) compared three different kinds of coffee, one Robusta and two Arabicas, following them from the farm gate to the retailer where consumers can buy the final product. At the farm gate the two kinds of Arabica coffee had identical prices (and not much more than the price of the Robusta type of coffee). In the end, however, one of these two kinds of Arabica coffee had a consumer price more than two and half times higher than that of the other, with the Robusta coffee drawing only about $10 \%$ of the sales price attached to the Arabica coffees (Daviron \& Ponte, 2005, pp. 210, 212).

How can these differences in price be explained? The explanation for the huge variance at the end of the chain is that the global value chains diverged in the dominant quality conventions in the middle of the chain (the process of roasting and retailing in Europe). It was at that intermediate point of the chain that different logics of quality convention-related coordination exerted their influence. As a result, the "quality" of the produced coffee was transformed into a different "ontology," and this new product ontology became related to a different style how the final product should be consumed: coffee as a mass-produced commodity sold at supermarkets for private consumption at home; or high-quality espresso coffee consumed in a coffee bar. It is not the raw material (at the beginning of the global value chain) that justifies the differences in price. Instead, it is the downstream difference in ways of coordinating production that creates a completely different perception of quality. The emerging question is how these global value chains are governed. It is obvious to refer to quality conventions as principles for the governance of the whole quality chain itself.

\footnotetext{
${ }^{8}$ The concept of the global value chain was developed from the commodity-chain concept (Gereffi \& Korzeniewicz, 1994) and the global-value-chain concept (Gereffi, Humphrey, \& Sturgeon, 2005).
} 


\section{Summary}

Economics of convention is a transdisciplinary and complex pragmatist form of institutionalism. It should be thought of not as a stringent body of theory but rather as a scientific movement that has developed concepts in the course of empirical institutional research. Its core arguments and principles relevant to the study of institutions and knowledge can briefly be summarized.

1. This institutionalism has conceptualized approached knowledge by positing conventions as implicit, collective frames of knowledge that coordinating actors must draw on in situations in order to deal with institutions. In addition, economics of convention offers a perspective from which to understand knowledge as deeper structures of discourses.

2. From an institutionalist perspective, economics of convention can be characterized also as an approach that differentiates institutions from conventions. This distinction is achieved through a constrained concept of institutions: institutions are the manifest (or formal) dispositives for coordination, but the manner of their interpretation, relevance, and handling is open to and combinable with different conventions in situations - four of which were identified in this chapter. Institutions, seen this way, need to be embedded in convention-based and convention-structured forms of knowledge. Economics of convention frames institutions not as external to action and coordination but rather as internal to them.

3. Two main models of how conventions can be theorized and systematized were introduced: the set of quality conventions and the set of worlds of productions. They are closely interrelated, and both sets have been used in many studies based on the economics of convention. The worlds-of-production model has been applied especially in regional and geographical economic research. The model of quality conventions has figured in the analysis of market structures and global value chains.

4. Two empirical applications of economics of convention were presented. They demonstrate how the plurality of quality conventions structures different market segments and the different forms of segmental market knowledge (the wine example). They also show how quality chains (the coffee example) combine quality conventions in various ways and thereby result in different perceptions of quality among consumers) - even when the raw material is similar.

5. Unlike its institutionalist counterpart-transaction cost analysis (Williamson, 1985) - economics of convention regards product ontology not as a given property but rather as the result of convention-based coordination and perception. Discourses and conventions as deeper knowledge structures are essential to generate qualities collectively. In economics of convention, there is no one best way to design economic institutions. Instead, there is a coexisting plurality of quality conventions or worlds of production as principles how to produce, distribute, and consume goods. 


\section{References}

Allaire, G., \& Boyer, R. (Eds.). (1995). La grande transformation de l'agriculture [The great transformation of agriculture]. Paris: INRA.

Bathelt, H., \& Glückler, J. (2011). The relational economy: Geographies of knowing and learning. Oxford, UK: Oxford University Press. doi:https://doi.org/10.1111/jors.12024_4

Batifoulier, P., Bessis, F., Ghirardello, A., de Larquier, G., \& Rémillon, D. (Eds.). (2016). Dictionnaire des conventions: Autour des travaux d'Olivier Favereau [Dictionary of conventions: On the work of Olivier Favereau]. Capitalismes-éthique-institutions: Vol. 10. Villeneuve-d'Ascq: Presses Universitaires du Septentrion.

Bessy, C. (2012). Law, forms of organization and the market for legal services. Economic Sociology: The European Electronic Newsletter, 14(1), 20-30. Retrieved from http://econsoc. mpifg.de/archive/econ_soc_14-1.pdf

Bessy, C. \& Chateauraynaud, F. (2014). Experts et faussaires. 2nd ed. Paris: Edition Petra.

Boltanski, L., \& Chiapello, E. (2005). The new spirit of capitalism (G. Elliott, Trans.). London: Verso Books. (Original work published 1999)

Boltanski, L., \& Thévenot, L. (1983). Finding one's way in social space: A study based on games. Social Science Information, 22, 631-680. doi:https://doi.org/10.1177/053901883022004003

Boltanski, L., \& Thévenot, L. (2006). On justification: Economies of worth (C. Porter, Trans.). Princeton: Princeton University Press. (Original work published 1991)

Boltanski, L., \& Thévenot, L. (Eds.). (1989). Justesse et justice dans le travail [Appropriateness and justice at work]. Cahiers du Centre d'études de l'emploi: Vol. 33. Paris: Presses Universitaires de France.

Corcuff, P. (2011). Les nouvelles sociologies: Entre le collectif et l'individuel [The new sociologies: Between the collective and the individual] (3rd ed.). Paris: Armand Colin.

Daviron, B., \& Ponte, S. (2005). The coffee paradox: Global markets, commodity trade and the elusive promise of development. London: Zed Books.

Diaz-Bone, R. (2013). Discourse conventions in the construction of wine qualities in the wine market. Economic Sociology: The European Electronic Newsletter, 14(2), 46-53. Retrieved from http://econsoc.mpifg.de/archive/econ_soc_14-2.pdf

Diaz-Bone, R. (2018). Die "Economie des conventions": Grundlagen und Entwicklung der neuen französischen Wirtschaftssoziologie [The economics of convention: Foundations and developments of new French economic sociology] (2nd ed.). Wiesbaden: Springer VS.

Diaz-Bone, R., Didry, C., \& Salais, R. (Eds.). (2015). Law and conventions from a historical perspective [Special issue]. Historical Social Research, 40(1). Retrieved from http://www.gesis. org/en/hsr/archive/2015/401-law-and-conventions/

Diaz-Bone, R., \& Salais, R. (Eds.). (2011). Conventions and institutions from a historical perspective [Special issue]. Historical Social Research, 36(4). Retrieved from http://www.gesis.org/ hsr/archiv/2011/364-conventions-institutions/

Diaz-Bone, R., \& Salais, R. (Eds.). (2012). The Économie des Conventions: Transdisciplinary discussions and perspectives [Special issue]. Historical Social Research, 37(4). Retrieved from http://www.gesis.org/en/hsr/archive/2012/374-the-economie-des-conventions/

Didry, C. (2002). Naissance de la convention collective: Débats juridiques et luttes sociales en France au début du XX $X^{e}$ siècle [Birth of the collective convention: Legal debate and social conflict in France in the early twentieth century]. Paris: Editions de l'EHESS.

Dosse, F. (1998a). The rising sign, 1945-1966 (D. Glassman, Trans.). History of Structuralism: Vol. 1. Minneapolis: University of Minnesota Press. (Original work published 1991)

Dosse, F. (1998b). The sign sets, 1967-present (D. Glassman, Trans.). History of Structuralism: Vol. 2. Minneapolis: University of Minnesota Press. (Original work published 1992)

Dosse, F. (1999). Empire of meaning: The humanization of the social sciences (H. Melehy, Trans.). Minneapolis: University of Minnesota Press. (Original work published 1995)

Eymard-Duvernay, F., \& Thévenot, L. (1983). Les investissements de forme: Leur usage pour la main d' œuvre [Form investments: Their use for the craft trades]. Paris: INSEE. 
Favereau, O. (1989a). Marchés internes, marchés externes [Internal markets, external markets]. Revue économique, 40, 273-328. doi:https://doi.org/10.2307/3502116

Favereau, O. (1989b). Organisation et marché [Organization and market]. Revue française d'économie, 4, 65-96. doi:https://doi.org/10.3406/rfeco.1989.1203

Favereau, O. (1997). L'incomplétude n'est pas le problème, c'est la solution [The incompleteness is not the problem-it is the solution]. In B. Reynaud (Ed.), Les figures de collectif (pp. 219-233). Les limites de la rationalité: Vol. 2. Paris: La Découverte.

Favereau, O. (2014). "Société" par nécessité, "entreprise” par convention ["Society" by necessity, "enterprise” by convention]. In B. Segrestin, B. Roger, \& S. Vernac (Eds.), L'entreprise: Point aveugle du savoir (pp. 48-64). Paris: Sciences Humains.

Favereau, O., \& Lazega, E. (Eds.). (2002). Conventions and structures in economic organization: Markets, networks, hierarchies. Cheltenham: Edward Elgar.

Gereffi, G., J. Humphrey, \& Sturgeon, T. (2005). The governance of global value chains. Review of International Political Economy, 12, 78-104. doi:https://doi.org/10.1080/09692290500049805

Gereffi, G., \& Korzeniewicz, M. (Eds.). (1994). Commodity chains and global capitalism. Westport: Greenwood.

Gomez, P-Y., \& Jones, B. C. (2000). Crossroads-Conventions: An interpretation of deep structure in organizations. Organization Science, 11, 696-708. doi:https://doi.org/10.1287/ orsc.11.6.696.12530

Hutchins, E. (1995). Cognition in the wild. Cambridge, MA: MIT Press.

James, W. (1909). A pluralistic universe: Hibbert lectures at Manchester College on the present situation in philosophy. London: Longmans, Green \& Company.

Knoll, L. (Ed.). (2015). Organisationen und Konventionen: Die Soziologie der Konventionen in der Organisationsforschung [Organizations and conventions: The sociology of conventions in organization studies]. Wiesbaden: Springer VS.

Kuklick, B. (2001). A history of philosophy in America: 1720-2000. Oxford, UK: Oxford University Press.

Latsis, J. (2006). Convention and intersubjectivity: New developments in French economics. Journal for the Theory of Social Behaviour, 36, 255-277. doi:https://doi. org/10.1111/j.1468-5914.2006.00307.x

Meyer, J. W., \& Rowan, B. (1977). Institutionalized organizations: Formal structure as myth and ceremony. American Journal of Sociology, 83, 340-363. doi:https://doi.org/10.1086/226550

Nachi, M. (2006). Introduction à la sociologie pragmatique [Introduction to pragmatic sociology]. Paris: Armand Colin.

Nicolas, F., \& Valceschini, E. (Eds.). (1995). Agro-alimentaire: Une économie de la qualité [Agrofood industry: An economy of qualities]. Paris: INRA/Economica.

North, D. C. (1990). Institutions, institutional change and economic performance. Cambridge, UK: Cambridge University Press.

Orléan, A. (2014). The empire of value: A new foundation for economics (M. B. DeBevoise, Trans.). Cambridge, MA: MIT Press.

Piore, M. J., \& Sabel, C. F. (1984). The second industrial divide: Possibilities for prosperity. New York: Basic Books.

Ponte, S. (2016). Convention theory in the Anglophone agro-food literature: Past, present and future. Journal of Rural Studies, 44(4), 12-23. doi:https://doi.org/10.1016/j.jrurstud.2015.12.019

Posner, R. A. (2007). Economic analysis of law (7th ed.). New York: Aspen.

Powell, W. W., \& DiMaggio, P. J. (Eds.). (1991). The new institutionalism in organizational analysis. Chicago: University of Chicago Press.

Salais, R., Baverez, N., \& Reynaud, B. (1999). L'invention du chômage: Histoire et transformations d'une catégorie en France des années 1890 aux années 1980 [The invention of unemployment: History and transformations of a category in France between the 1890s and the 1980s]. Quadrige: Vol. 286. Paris: Presses Universitaires de France.

Sánchez-Hernández, J. S., Aparicio-Amador, J. \& Alonso-Santos, J. (2010). The shift between worlds of production as an innovative process in the wine industry in Castile and Leon (Spain). Geoforum, 41, 469-478. doi:https://doi.org/10.1016/j.geoforum.2009.12.004 
Storper, M. (1997). The regional world: Territorial development in a global economy. New York: Guilford Press.

Storper, M., \& Salais, R. (1997). Worlds of production: The action frameworks of the economy. Cambridge, MA: Harvard University Press.

Thévenot, L. (2001). Organized complexity: Conventions of coordination and the composition of economic arrangements. European Journal of Social Theory, 4, 405-425. doi:https://doi. org/10.1177/13684310122225235

Weber, M. (1978). Economy and society: An outline of interpretive sociology. 2 Vols. (G. Roth \& C. Wittich, Eds.; E. Fischoff, H. Gerth, A. M. Henderson, F. Kolegar, C. Wright Mills, T. Parsons, M. Rheinstein, G. Roth, E. Shils, \& C. Wittich, Trans.). Berkeley: University of California Press. (Original work published 1922)

Williamson, O. E. (1985). The economic institutions of capitalism: Firms, markets, relational contracting. New York: Free Press.

Open Access This chapter is licensed under the terms of the Creative Commons Attribution 4.0 International License (http://creativecommons.org/licenses/by/4.0/), which permits use, sharing, adaptation, distribution and reproduction in any medium or format, as long as you give appropriate credit to the original author(s) and the source, provide a link to the Creative Commons license and indicate if changes were made.

The images or other third party material in this chapter are included in the chapter's Creative Commons license, unless indicated otherwise in a credit line to the material. If material is not included in the chapter's Creative Commons license and your intended use is not permitted by statutory regulation or exceeds the permitted use, you will need to obtain permission directly from the copyright holder. 